\title{
Evaluation of Maternal and Neonatal Outcomes in Cesarean Sections Performed in the Second Stage of Labor
}

\author{
(D) Fatma Didem Yücel Yetişkin, (D) Burak Arslan, (D) Veli Mihmanlı, (D) Büşra Cambaztepe, (D) Gizem Pektaş, (1) Aras Pektaş \\ University of Health Sciences, İstanbul Okmeydanı Training and Research Hospital, Department of Obstetrics and Gynecology, İstanbul, Turkey
}

\section{Abstract}

Objective: To compare maternal and neonatal outcomes in cesarean deliveries in the first and second stage of labor.

Methods: Sixty-five patients who had caesarean section in the second stage of labor and 90 patients who had caserean section in the first stage of labor were compared in terms of maternal and neonatal complications. Patient data was obtained from patient files and hospital electronic system records.

Results: Of the 155 patients included in the study, 58.1\% $(n=90)$ had a cesarean section in the first stage of labor and $41.9 \%$ ( $n=65)$ in the second stage of labor. The incidence of intraoperative surgical complication and postoperative endomyometritis was significantly higher in the cesarean section in the second stage of labor compared to the cesarean section in the first stage of labor. There was no significant difference in terms of blood transfusion requirement and neonatal complications between two groups.

Conclusion: Maternal morbidity risk is significantly higher in cesarean sections performed in the second stage of labor than in the first stage of labor. Keywords: Cesarean section, maternal outcomes, neonatal outcomes, second phase of the labor

\section{INTRODUCTION}

The rate of caesarean section in the world is increasing and it has reached $50 \%$ today (1). In our country, this ratio was around 6\% between 1983-2001 and now it has increased up to 30\% (2). The World Health Organization (WHO) reports that the cesarean birth rate should be less than 15\% (3). Maternal mortality was reported to be 6/100000 in vaginal delivery and 28/100000 in cesarean delivery in healthy pregnant women without medical and obstetric problems (4). Maternal morbidities are also higher in cesarean deliveries than vaginal deliveries. Complications such as postpartum febrile morbidity, deep vein thrombosis, need for blood transfusion, long hospital stay, organ injuries, intraabdominal adhesions, infertility and chronic pelvic pain are also more frequent in cesarean delivery (5).
Van Ham et al. (6) and Nielsen et al. (7) reported intraoperative surgical complication rates as $11.6 \%$ and $14.8 \%$ in cesarean deliveries. Regular uterine contractions, presence of membrane rupture, cervical patency more than $3 \mathrm{~cm}$, and engagement are the most important risk factors for intraoperative complication development (7-9). In this study, 155 term primary cesarean section patients were divided into two groups as cesarean section in the "first" and "second" stages of labor, and age, gravida, parity, gestational week, caesarean indication, hospital stay, blood transfusion requirement, maternal outcomes such as intraoperative and postoperative surgical complications, and neonatal outcomes such as fetal birth weight, Apgar score and neonatal intensive care requirement were compared. 


\section{METHODS}

Istanbul Okmeydanı Training and Research Hospital Ethics Committee approved this study (no: 253, dated 23.12.2014). This study was performed by examining the records of cesarean section patients at the Obstetrics and Gynecology Clinic of Okmeydanı Training and Research Hospital between 2010 and 2014. Sixty-five patients who had caesarean section in the second stage of labor and 90 patients who had caserean section in the first stage of labor were compared in terms of maternal and neonatal complications. Patients with maternal diseases (hypertension, heart disease, diabetes mellitus, etc.) and those with fetal anomalies were not included in the study group.

\section{Statistical Analysis}

The statistical analysis was performed using Number Cruncher Statistical System (NCSS) 2007 program.

\section{RESULTS}

The maternal and fetal characteristics of the patients included in the study are presented in Table 1 . The mean age of the patients was $27.52 \pm 6.42$ years (18-40 years), mean gravida was $2.17 \pm 1.43$ (1-8), mean parity was $0.90 \pm 1.21$ (0-5), and mean gestational age was $38.32 \pm 0.91$ weeks (37-40 weeks). The mean length of hospital stay was $2.58 \pm 0.78$ days (2-7 days). The mean birth weight was $3449.43 \pm 403.44$ grams (2470-4560 grams). The mean 1-minute and 5-minute Apgar scores were 7.88 $\pm 0.72(3-9)$ and $8.23 \pm 0.82$ (7-9). Fifty-eight point one percent $(n=90)$ of the cesarean sections occurred in the first stage and $41.9 \%(n=65)$ occurred in the second stage of labor.

\begin{tabular}{|c|c|c|c|}
\hline & Min-max & \multicolumn{2}{|c|}{ Mean \pm SD } \\
\hline Age, years & $18-40$ & \multicolumn{2}{|c|}{$27.52 \pm 6.42$} \\
\hline Gravida & $1-8$ & \multicolumn{2}{|c|}{$2.17 \pm 1.43$} \\
\hline Parity & $0-5$ & \multicolumn{2}{|c|}{$0.90 \pm 1.21$} \\
\hline Weeks of pregnancy & $37-40$ & \multicolumn{2}{|c|}{$38.32 \pm 0.91$} \\
\hline Length of hospital stay (days) & $2-7$ & \multicolumn{2}{|c|}{$2.58 \pm 0.78$} \\
\hline Birth weight (gr) & $2470-4560$ & \multicolumn{2}{|c|}{$3449.43 \pm 403.44$} \\
\hline 1-minute Apgar & $3-9$ & \multicolumn{2}{|c|}{$7.88 \pm 0.72$} \\
\hline 5-minute Apgar & $4-9$ & \multicolumn{2}{|c|}{$8.23 \pm 0.82$} \\
\hline & & $\mathrm{n}$ & $\%$ \\
\hline \multirow{2}{*}{ Birth weight } & $<4000 \mathrm{gr}$ & 138 & 89 \\
\hline & $\geq 4000 \mathrm{gr}$ & 17 & 11 \\
\hline \multirow{2}{*}{ Birth stage } & 1st stage & 65 & 41.9 \\
\hline & 2nd stage & 90 & 58.1 \\
\hline
\end{tabular}

Findings related to maternal and fetal mortality and morbidity after cesarean section are presented in Table 2. Maternal complications were as follows: blood transfusion in 25 patients, B-Lynch sutures due to atony hemorrhage in one patient, T-shape incision in one patient, hematoma in two patients, extended incision in nine patients, bladder injury in two patients and postpartum endometritis in 18 patients. Neonatal complications included need for intensive care in 23 newborns and 2 neonatal deaths.

The cesarean indications are given in Table 3.

There was no statistically significant difference between the two groups in terms of age, gravida, parity, gestational week, hospital stay, 1-minute and 5-minute Apgar scores and birth weight $(p>0.05)$ (Table 4).

Surgical complications and postpartum endometritis were found to be higher in cesarean sections in the second stage of labor $(p=0.06 ; p<0.01)$. The difference between two groups in terms of neonatal intensive care need, neonatal mortality and maternal blood transfusion rates was not statistically significant $(\mathrm{p}>0.05)$ (Table 5).

The indications of the patients who had cesarean section in the first stage of labor were fetal distress, cephalopelvic disproportion (CPD) and obstructed labor, respectively. The indications of the patients who had cesarean section in the second stage of labor were CPD, obstructed labor and fetal distress, respectively (Table 6).

Table 2. Findings related to maternal and neonatal morbidity and mortality

\begin{tabular}{|l|l|l|l|}
\hline \multicolumn{2}{|c|}{} & $n$ & $\%$ \\
\hline \multirow{2}{*}{ Blood transfusion } & No & 130 & 83.9 \\
\cline { 2 - 4 } & Yes & 25 & 16.1 \\
\hline \multirow{2}{*}{ Surgical complication } & No & 140 & 90.3 \\
\cline { 2 - 4 } & Yes & 15 & 9.7 \\
\hline B-Lynch suture & 1 & 6.7 \\
\hline Hematoma & 2 & 13.3 \\
\hline Extended incision & 9 & 60.0 \\
\hline Bladder injury & 2 & 13.3 \\
\hline T-shape incision & 1 & 6.7 \\
\hline Postpartum hysterectomy & - & - \\
\hline Postpartum endometritis & 18 & 11.6 \\
\hline Maternal mortality & - & - \\
\hline Need for neonatal intensive care & 23 & 14.8 \\
\hline Neonatal mortality & 2 & 1.3 \\
\hline
\end{tabular}




\section{DISCUSSION}

In the United States, the cesarean section rate of $2 \%$ was under discussion in 1958, whereas it was increased to $24.1 \%$ in 1986 (10). Although there has been a decrease in cesarean rates in the 1990s due to the increase in maternal morbidity and increase in operating costs with no change in infant mortality, the rate of caesarean section in USA is approximately $22 \%$ (10). According to the data of the Ministry of Health in Turkey, the rate of caesarean section was 14\% in 1998 and it was reported as 50.4\% in 2013. In the retrospective studies conducted in our country, the rate of caesarean section varies between $18 \%$ and 33\% (11-13).

The main reason for the increase in cesarean section rates is the expansion of indication groups, including previous cesarean section, CPD, breech presentation, fetal distress and obstructed labor. In addition, elective caesarean section preferences have increased because of the thought of less pain, less harm to the pelvic organs and more benefits for the fetus (14). Increased cesarean indications increase recurrent cesarean section cases. The most common caesarean section indication in our country is recurrent cesarean section and the rate is $30 \%$ (15).

In many clinics, fetal distress indication is performed by fetal electronic monitoring. This method has a high false positive rate and intrapartum fetal monitoring application

\begin{tabular}{|l|l|l|}
\hline \multicolumn{3}{|l|}{ Table 3. Findings related to cesarean indications } \\
\hline & $\mathbf{n}$ & $\%$ \\
\hline CPD & 49 & 31.6 \\
\hline Fetal distress & 34 & 21.9 \\
\hline Obstructed labor & 30 & 19.4 \\
\hline Dense meconium & 13 & 8.4 \\
\hline Breech presentation & 10 & 6.5 \\
\hline Other indications (HPV, large baby etc.) & 39 & 25.2 \\
\hline Anhydramnios & 6 & 3.87 \\
\hline Placental detachment & 4 & 2.58 \\
\hline Previous lumbar surgery & 1 & 0.65 \\
\hline HPV & 5 & 3.23 \\
\hline Precious pregnancy & 1 & 0.65 \\
\hline Cord prolapse & 3 & 1.94 \\
\hline Chorioamnionitis & 1 & 0.65 \\
\hline Macrosomia & 9 & 5.81 \\
\hline Meconium + large baby & 1 & 0.65 \\
\hline Transverse presentation & 2 & 2.58 \\
\hline Umbilical hernia surgery & 1 & 0.65 \\
\hline Incompatible patient & 2 & 1.29 \\
\hline Face presentation & 4 & 0.65 \\
\hline CPD: Cephalopelvic disproportion, HPV: Human papillomavirus & \\
\hline
\end{tabular}

also contributes to the increase in cesarean rate $(15,16)$. In a Cochrane database review, the authors reported that fetal

Table 4. Evaluation of maternal and fetal properties with birth stage of cesarean section

\begin{tabular}{|c|c|c|c|c|}
\hline & \multicolumn{2}{|c|}{ Birth stage } & \multirow[t]{2}{*}{$p$} \\
\hline & & $\begin{array}{l}\text { 1st stage } \\
(\mathrm{n}=90)\end{array}$ & $\begin{array}{l}2^{\text {nd }} \text { stage } \\
(n=65)\end{array}$ & \\
\hline \multirow[b]{2}{*}{ Age } & Mean \pm SD & $28.04 \pm 6.57$ & $26.80 \pm 6.19$ & \multirow[b]{2}{*}{$\mathrm{a} 0.235$} \\
\hline & $\begin{array}{l}\text { Min-max } \\
\text { (median) }\end{array}$ & $18-40(28)$ & $18-40(27)$ & \\
\hline \multirow[b]{2}{*}{ Gravida } & Mean \pm SD & $2.19 \pm 1.53$ & $2.15 \pm 1.30$ & \multirow[b]{2}{*}{$b_{0} 0.693$} \\
\hline & $\begin{array}{l}\text { Min-max } \\
\text { (median) }\end{array}$ & $1-8(1.50)$ & $1-6(2)$ & \\
\hline \multirow[b]{2}{*}{ Parity } & Mean \pm SD & $0.94 \pm 1.29$ & $0.85 \pm 1.10$ & \multirow[b]{2}{*}{ b0.973 } \\
\hline & $\begin{array}{l}\text { Min-max } \\
\text { (median) }\end{array}$ & $0-5(0)$ & $0-4(0)$ & \\
\hline \multirow{2}{*}{$\begin{array}{l}\text { Weeks of } \\
\text { pregnancy }\end{array}$} & Mean \pm SD & $38.33 \pm 0.93$ & $38.29 \pm 0.89$ & \multirow[b]{2}{*}{ b0.793 } \\
\hline & $\begin{array}{l}\text { Min-max } \\
\text { (median) }\end{array}$ & $37-40(38)$ & $37-40(38)$ & \\
\hline \multirow{2}{*}{$\begin{array}{l}\text { Length of } \\
\text { hospital } \\
\text { stay (days) }\end{array}$} & Mean \pm SD & $2.49 \pm 0.70$ & $2.71 \pm 0.86$ & \multirow[b]{2}{*}{ b0.057 } \\
\hline & $\begin{array}{l}\text { Min-max } \\
\text { (median) }\end{array}$ & $2-5(2)$ & 2-7 (3) & \\
\hline \multirow{2}{*}{$\begin{array}{l}\text { 1-minute } \\
\text { Apgar }\end{array}$} & Mean \pm SD & $7.88 \pm 0.71$ & $7.89 \pm 0.75$ & \multirow[b]{2}{*}{ b0.742 } \\
\hline & $\begin{array}{l}\text { Min-max } \\
\text { (median) }\end{array}$ & 6-9 (8) & $3-9(8)$ & \\
\hline \multirow{2}{*}{$\begin{array}{l}\text { 5-minute } \\
\text { Apgar }\end{array}$} & Mean \pm SD & $8.26 \pm 0.86$ & $8.20 \pm 0.77$ & \multirow[b]{2}{*}{ b0.321 } \\
\hline & $\begin{array}{l}\text { Min-max } \\
\text { (median) }\end{array}$ & 6-9 (8) & 4-9 (8) & \\
\hline \multirow{2}{*}{$\begin{array}{l}\text { Birth } \\
\text { weight; n } \\
\text { (\%) }\end{array}$} & $<4000 \mathrm{gr}$ & 82 (91.1) & $56(86.2)$ & \multirow{2}{*}{${ }^{c} 0.330$} \\
\hline & $>4000 \mathrm{gr}$ & $8(8.9)$ & 9 (13.8) & \\
\hline
\end{tabular}

SD: Standard deviation, Min: Minimum, Max: Maximum, aStudent's t-test, ${ }^{b}$ MannWhitney $\mathrm{U}$ test, cPearson chi-square test

Table 5. Evaluation of maternal and fetal outcomes with birth stage of cesarean section

\begin{tabular}{|c|c|c|c|c|}
\hline & \multicolumn{2}{|c|}{ Birth stage } & \multirow[t]{2}{*}{$p$} \\
\hline & & $\begin{array}{l}1^{\text {st }} \text { stage } \\
(\mathrm{n}=90)\end{array}$ & $\begin{array}{l}2^{\text {nd }} \text { stage } \\
(n=65)\end{array}$ & \\
\hline \multirow{2}{*}{$\begin{array}{l}\text { Postpartum } \\
\text { endometritis }\end{array}$} & No & $85(94.4)$ & $52(80.0)$ & \multirow{2}{*}{$\mathrm{a} 0.006^{* *}$} \\
\hline & Yes & $5(5.6)$ & $13(20.0)$ & \\
\hline \multirow{2}{*}{$\begin{array}{l}\text { Neonatal intensive } \\
\text { care need }\end{array}$} & No & 75 (83.3) & $57(87.7)$ & \multirow{2}{*}{$\mathrm{a}^{0.451}$} \\
\hline & Yes & $15(26.7)$ & $8(12.3)$ & \\
\hline \multirow{2}{*}{ Neonatal mortality } & No & $88(97.8)$ & $65(100.0)$ & \multirow{2}{*}{$b_{0} 0.510$} \\
\hline & Yes & $2(2.2)$ & - & \\
\hline \multirow{2}{*}{ Blood transfusion } & No & $78(86.7)$ & $52(80.0)$ & \multirow{2}{*}{$\mathrm{a}^{0.265}$} \\
\hline & Yes & $12(13.3)$ & $13(20.0)$ & \\
\hline \multirow{2}{*}{ Surgical complication } & No & $86(95.6)$ & $54(83.1)$ & \multirow{2}{*}{$\mathrm{a} 0.010^{* *}$} \\
\hline & Yes & $4(4.4)$ & $11(16.9)$ & \\
\hline
\end{tabular}


monitoring increased the cesarean section frequency by $40 \%$, but did not significantly reduce the incidence of admission and cerebral palsy in the neonatal intensive care unit (17). In our study, fetal distress indication was in second place among the indications for primary cesarean sections with a rate of $21.9 \%$. This rate is reported to be $21.6 \%$ at Șișli Etfal Hospital (18), 16.3\% in Obstetrics and Gynecology Clinic of Dicle University Faculty of Medicine (19) and 19.1\% in Obstetrics and Gynecology Clinic of Yüzüncü Yıl University Faculty of Medicine (20). The primary cesarean section rate is $9.7 \%$ in the United States (21).

In a study in which 34995 cases were included, intrapartum fetal monitoring was evaluated and it was determined that more cesarean decisions were made in the group in which all pregnant women were monitored compared to the selective

\begin{tabular}{|c|c|c|c|c|}
\hline \multirow{3}{*}{\multicolumn{2}{|c|}{$\begin{array}{l}\text { Table } 6 \text {. Evaluation of indicat } \\
\text { cesarean section }\end{array}$}} & ions accor & ng to birtl & stage of \\
\hline & & \multicolumn{2}{|c|}{ Birth stage } & \multirow[b]{2}{*}{$\mathbf{p}$} \\
\hline & & $\begin{array}{l}\text { 1st stage } \\
(\mathrm{n}=90)\end{array}$ & $\begin{array}{l}2^{\text {nd }} \text { stage } \\
(\mathrm{n}=65)\end{array}$ & \\
\hline \multirow{2}{*}{ CPD } & No & $71(78.9)$ & $35(53.8)$ & \multirow{2}{*}{$\mathrm{a} 0.001 * *$} \\
\hline & Yes & $19(21.1)$ & $30(46.2)$ & \\
\hline \multirow{2}{*}{ Fetal distress } & No & $68(75.6)$ & $53(81.5)$ & \multirow{2}{*}{$\mathrm{a} 0.374$} \\
\hline & Yes & $22(24.4)$ & $12(18.5)$ & \\
\hline \multirow{2}{*}{ Obstructed labor } & No & $74(82.2)$ & $51(78.5)$ & \multirow{2}{*}{$\mathrm{a} 0.559$} \\
\hline & Yes & $16(17.8)$ & $14(21.5)$ & \\
\hline \multirow{2}{*}{ Dense meconium } & No & $81(90.0)$ & $61(93.8)$ & \multirow{2}{*}{$\mathrm{a} 0.394$} \\
\hline & Yes & $9(10.0)$ & $4(6.2)$ & \\
\hline \multirow{2}{*}{ Breech presentation } & No & $84(93.3)$ & $61(93.8)$ & \multirow{2}{*}{$b^{1} .000$} \\
\hline & Yes & $6(6.7)$ & $4(6.2)$ & \\
\hline \multirow{2}{*}{$\begin{array}{l}\text { Other indications } \\
\text { (HPV, large baby etc.) }\end{array}$} & No & $59(65.6)$ & $57(87.7)$ & \multirow{2}{*}{$\mathrm{a} 0.002^{* *}$} \\
\hline & Yes & $31(34.4)$ & $8(12.3)$ & \\
\hline \multicolumn{2}{|l|}{ Anhydramnios } & 6 & 0 & \\
\hline \multicolumn{2}{|l|}{ Placental detachment } & 3 & 1 & \\
\hline \multicolumn{2}{|l|}{ Previous lumbar surgery } & 1 & 0 & \\
\hline \multicolumn{2}{|l|}{ HPV } & 4 & 1 & \\
\hline \multicolumn{2}{|l|}{ Precious pregnancy } & 1 & 0 & \\
\hline \multicolumn{2}{|l|}{ Cord prolapse } & 2 & 1 & \\
\hline \multicolumn{2}{|l|}{ Chorioamnionitis } & 1 & 0 & \\
\hline \multicolumn{2}{|l|}{ Macrosomia } & 6 & 3 & \\
\hline \multicolumn{2}{|l|}{ Meconium + large baby } & 0 & 1 & \\
\hline \multicolumn{2}{|l|}{ Transverse presentation } & 4 & 0 & \\
\hline \multicolumn{2}{|l|}{ Umbilical hernia surgery } & 1 & 0 & \\
\hline \multicolumn{2}{|l|}{ Incompatible patient } & 2 & 0 & \\
\hline \multicolumn{2}{|c|}{ Face presentation } & 0 & 1 & \\
\hline \multicolumn{5}{|c|}{ CPD: Cephalopelvic disproportion, HPV: Human papillomavirus } \\
\hline
\end{tabular}

monitorization group, but there was no difference in perinatal results (22). In our study, there was no statistically significant difference between the groups in terms of 5-minute Apgar score and need for neonatal intensive care unit.

In the studies, no cause-effect relationship was found between the increase in cesarean rates and the decrease in perinatal mortality and morbidity. It was reported that the factors affecting perinatal mortality are only the presentation of the fetus, maternal diseases leading to pregnancy complications, number of fetuses, ethnicity and maternal age (23). Respiratory distress syndrome type-II incidence rate in vaginal deliveries after $37^{\text {th }}$ gestational week is 5.3 , whereas this rate is $35.5 \%$ for cesarean sections not in labor and $12.2 \%$ for cesarean section in labor (24). In another study in neonates between 37-42 weeks of gestation, an increase was observed in all morbidities in cesarean sections not in labor compared to spontaneous, elective or induced vaginal deliveries. The ventilator requirement is 4.51 times, the asphyxia is 4.91 times, the sepsis is 1.40 times, and the intensive care unit stay was 1.98 times more (25). In our study, neonatal mortality rate was calculated as $14.8 \%$ and neonatal mortality rate was calculated as $1.3 \%$. Need for neonatal intensive care unit and neonatal mortality were comparable between those with cesarean section in the $1^{\text {st }}$ stage and those with cesarean section in the second stage of labor.

Although significant decrease in perinatal mortality and morbidity has been observed with widespread use of ultrasonography, it is a fact that this practice increases the cesarean rates. There is a 15\% margin of error in the predicted fetal weight in the last trimester. Although the term "fetal macrosomia" varies according to the populations, the type of delivery also varies according to the maternal pelvis structure. Deciding on only the expected birth weight increases the cesarean rate. In our study, the rate of those who underwent cesarean with the indication of macrosomia was $1.94 \%$. The reason for this low rate is that cesarean delivery due to this indication is made without entering into the active stage.

CPD causes prolongation of labor, physical and psychological fatigue of the mother, fetus to remain under stress or even traumatization, varying degrees of damage to the birth canal and more workload and concern to the person who follows the birth. Therefore, nowadays, the people who are interested in birth seek to predict CPD and find a treatment without delay to prevent any harm to the mother or the fetus. CPD cannot always be predicted and cesarean section with CPD diagnosis is increasing (26). CPD indication rate among patients who underwent cesarean section was reported as 5.6\% by Yumru et al., (15) and 7.3\% by Kara (27). In a study conducted in a university hospital in Senegal, CPD was 
the leading cause of caesarean section with a rate of 31\% (28). In our study, the rate of cesarean section with CPD indication was the leading cause with a rate of $31.6 \%$. The reason for this is that the patients included in the study were selected from cesarean section cases after the beginning of active labor. The reason for increased CPD in the second stage of labor is the avoidance from labor with intervention (vacuum-forceps).

In a WHO report published in 2002, maternal mortality due to caesarean section was reported to be $41 / 100.000$ in the United States and 160-220/100,000 in developing countries (29). The WHO perinatal health-related questionnaire showed that cesarean delivery increased the need for postpartum antibiotic use and maternal blood transfusion, but caused no significant reduction in maternal morbidity and mortality (30). Operative complications are more common in emergency cases than in elective cases (31). In our study, the rate of surgical complication in patients undergoing cesarean section in the first stage of labor was $4.4 \%$ and in patients in the second stage was $16.9 \%$.

In their study, Bagratee et al., (32) suggested that prophylactic antibiotic use in cesarean operations did not reduce postpartum complication rates such as febrile morbidity, wound infection, endometritis, pneumonia and postoperative infection morbidity. In contrast, Killian et al., (33) reported that less infection rates were detected in patients who received antibiotics in their study. Smaill and Hofmery (34) reported less frequent endometritis, wound infection and urinary infection in antibiotic users. In a study by Ehrenkranz et al., (35), the rate of infection in cesarean deliveries was found to be $0.9 \%$ for those who received antibiotic prophylaxis and $3.7 \%$ for those who did not. In our study, the pospartum endometritis rate was also found to be $11.6 \%$. Endometritis rate was found to be $5.6 \%$ in the first stage of labor and $20 \%$ in the second stage.

Lydon-Rochelle et al., (36) stated that cesarean delivery increases the risk of endometritis, wound infection and thromboembolism, and therefore, the length of hospital stay increases due to these complications. In our study, the mean hospital stay was 2.58 days, with a mean of 2.49 days in the first stage of labor and 2.71 days in the second stage of labor.

Haas et al., (37) noted that the most common intraoperative complication in cesarean delivery was uterocervical laceration and associated blood loss. In our study, intraoperative uterocervical laceration rate was $9.7 \%$. This rate was $4.4 \%$ for cesarean section in the first stage of labor and $16.9 \%$ for cesarean section in the second stage.

\section{CONCLUSION}

Maternal morbidities such as intraoperative uterocervical laceration and postpartum endometritis, which may increase the need for blood transfusions in cesarean section performed in the second stage of labor, are significantly higher in the $2^{\text {nd }}$ stage of labor. Therefore, in the presence of the necessary conditions, intervention (vacuum-forceps) delivery in the second stage of labor should be considered as an alternative to cesarean delivery. It may be encouraging to provide appropriate working conditions and environment that will allow physicians to make decisions based on obstetric conditions, away from legal concerns.

\section{Ethics}

Ethics Committee Approval: İstanbul Okmeydanı Training and Research Hospital Ethics Committee approved this study (no: 253, dated 23.12.2014).

Informed Consent: Retrospective study.

Peer-review: Externally peer-reviewed.

\section{Authorship Contributions}

Surgical and Medical Practices: F.D.Y.Y., V.M., B.C., G.P., A.P., Concept: F.D.Y.Y., Design: F.D.Y.Y., V.M., Data Collection or Processing: F.D.Y.Y., .M., B.C., G.P., A.P., Analysis or Interpretation: F.D.Y.Y., B.A., Literature Search: F.D.Y.Y., B.A., Writing: B.A.

Conflict of Interest: No conflict of interest was declared by the authors.

Financial Disclosure: The authors declared that this study received no financial support.

\section{REFERENCES}

1. Flamm BL, Newman LA, Thomas SJ, Fallon D, Yoshida MM. Vaginal birth after cesarean delivery: results of a 5-year multicenter collaborative study. Obstet Gynecol 1990;76:750-4.

2. Koc I. Increased cesarean section rates in Turkey. Eur J Contracept Reprod Health Care 2003;8:1-10.

3. World Health Organization. Appropriate technology for birth. Lancet $1985 ; 24: 436-7$

4. Lilford RJ, Groot VC, Moore PJ, Bingham P. The relative risks of caesarean section (intrapartum and elective ) and vaginal delivery: a detailed analysis to exclude the effects of medical disorders and other acute pre-exiting physiological disturbances. Br J Obstet Gynecol 1990;97:883-92.

5. Nielson TF, Hökegard KH. Postoperative cesarean section morbidity: a prospective study. Am J Obstet Gynecol 1983;146:911-6.

6. Nielsen TF, Hokegard KH. Cesarean section and intraoperative surgical complications. Acta Obstet Gynecol Scand 1984;63:103-11.

7. Van Ham MA, Van Dongen PW, Mulder J. Maternal consequences of caesarean 
section. A retrospective study of intra-operative and postoperative maternal complications of caesarean section during a 10-year period. Eur J Obstet Gynecol Reprod Biol 1997;74:1-6.

8. Smith JF, Hernandez C, Wax JR. Fetal laceration injury at cesarean delivery. Obstet Gynecol 1997;90:344-50.

9. Rosen MG, Dickinson JC, Westhoff CL. Vaginal birth after cesarean: a metaanalysis of morbidity and mortality. Obstet Gynecol 1991;77:465-535.

10. Sakala C. Medically unnecessary cesarean section births: introduction to a symposium. Soc Sci Med 1993;37:1177-275.

11. Güney M, Uzun E, Oral B, Sarıkan I, Bayhan G, Mungan T. Kliniğimizde 20012005 yılları arasında sezaryen oranı ve endikasyonları. Türk Jinekoloji ve Obstetrik Derneği Derg 2006;3:249-54.

12. Yılmaz E, Kara M, Okumuş B, Aran E. Ağrı il Merkezinde 2004 ve 2007 yıllarındaki Doğumların Karșılaștııılması. Perinatoloji Derg 2008;16:26-31.

13. Yıldız A, Köksal A, Çukurova K, Keklik A, Çelik N, İvit H. Bir Obstetri Kliniğinde 15 yıllık period süresince sezaryen oranları ve endikasyonlarının yıllara göre dağılımı. Nobel Med 2010;6:10-14.

14. Muula SD. Ethical and Practical Consideration of Women Choosing Cesarean Section Deliveries without "Medical Indication" in Developing Countries. Croat Med J 2007;48:94-102.

15. Yumru E, Davas I, Baksu B, Altıntaş A, Altın A, Mert M. 1995-1999 yılları arasında sezaryan operasyonu oranları ve endikasyonları. Perinatoloji Derg 2000;8:94-8

16. Penna L, Arulkumaran S. Cesarean section for non-medical reasons. International Journal of Gynecology and Obstetrics 2003;82:399-409.

17. Thacker SB, Stroup D, Chang M. Continuous electronic fetal heart rate monitoring for fetal assessment during labor. Cochrane Database Syst Rev 2001:CD000063.

18. Dayan A. 3. Kadın Hastalıkları ve Doğum Kliniğinde sezaryen insidansı ve endikasyonlarının değerlendirilmesi. Uzmanlık Tezi 1999

19. Bayhan G, Yalınkaya A, Yayla M, Yalınkaya Ö, Erden AC. Kliniğimizde 1995-1999 yılları arasında yapılan sezaryenlerin ve sezaryen esnasında yapılan diğer operasyonların değerlendirilmesi. Klinik Bilimler ve Doktor 2000;6:249-300.

20. Gül A, Șimșek Y. Yüzüncü Yıl Üniversitesi Tıp Fakültesi Kadın Hastalıkları ve Doğum Kliniğinde 1996-1998 yılları arasında sezaryen oranı ve endikasyonları. Perinatoloji Derg 1998;6:10-2

21. Notzon FC, Cnattingius S, Bergio P, Cole S, Taffel S, Irgens L, et al. Cesarean section delivery in the 1980s: international comparison by indication. Am Obstet Gynecol 1994;170:495-504.

22. Leveno KJ, Cunningham FG. A prospective comparison of elective and universal electronic fetal monitoring in 34995 pregnancies. N Eng J Med 1986;4:615-24.
23. Grisaru S, Samueloff A. Primary nonmedically indicated cesarean section ("section on request"): evidence based or modern vogue? Clin Perinatol 2004;31:409-39.

24. Parilla BV, Dooley SL, Jansen RD, Socol ML. Iatrogenic respiratory distress syndrome following elective repeat cesarean delivery. Obstet Gynecol 1993:81:392-7.

25. Bailit JL, Gregory KD, Reddy UM, Gonzalez-Quintero VH, Hibbard JU, Ramirez $\mathrm{MM}$, et al. Maternal and neonatal out-comes by labor onset type and gestational age. Am J Obstet Gynecol 2010;202:245-57.

26. Rouse DJ, Owen J, Goldenberg RL, Cliver CP. The effectiveness and cost of elective cesarean delivery for fetal macrosomy diagnosed by ultrasound. JAMA 1996;276:1480-5.

27. Kara FŞ. Haseki Eğitim ve Araștırma Hastanesi Kadın Hastalıkları ve Doğum Kliniğinde İki Yıllık Sürede Sezaryen Doğumların Değerlendirilmesi (uzmanlık tezi), İstanbul, Haseki Eğitim ve Araștırma Hastanesi 2004.

28. Cisse CT, Ngom PM, Guissé A, Faye EO, Moreau JC. Thinking about the evolution of caeserean section rate at University Teaching Hospital of Dakar between 1992 and 2001. Gynecol Obstet Fertil 2004;32:210-7.

29. Global and regional estimates of incidence of a mortality due to unfase abortion. WHO report 2002.

30. Villar J, Valladares E, Wojdyla D, Zavaleta N, Carroli G, Velazco A, et al. WHO 2005 global survey on maternal and perinatal health research group. Cesarean delivery rates and pregnancy out-comes: the 2005 WHO global survey on maternal and perinatal health in Latin America. Lancet 2006;367:1819-48.

31. Miller JM. Maternal and neonatal morbidity and mortality in cesarean section. Obstet Gynecol Clin North Am 1988;15:629-67.

32. Bagratee JS, Moodley J, Kleinschmidt I, Zawilski WA. Randomised controlled trial of antibiotic prophylaxis in elective caesarean delivery. BJOG 2001;108:143-8.

33. Killian CA, Graffunder EM, Vinciguerra TJ, Venezia RA. Risk factors for surgical-site infections following cesarean section. Infect Control Hosp Epidemiol 2001;22:613-7.

34. Smaill F, Hofmeyr GJ. Antibiotic prophylaxis for cesarean section. Cochrane Database Syst Rev 2002:CD000933.

35. Ehrenkranz NJ, Blackwelder WC, Pfaff SJ, Poppe D, Yerg DE, Kaslow RA. Infections complicating low risk cesarean section in community hospitals: efficacy of antimicrobial prophylaxis. Am J Obstet Gynecol 1990;162:33778.

36. Lydon-Rochelle M, Holt VL, Martin DP, Easterling TR. Association between method of delivery and maternal rehospitalization. JAMA 2003;289:467.

37. Haas DM, Ayres AW. Laceration injury at cesarean section. J Matern Fetal Neonatal Med 2002;11:196-204. 